\title{
THE SYNDROME OF HYPOPARATHYROIDISM AND STEATORRHOEA
}

\author{
BY \\ EIRIAN WILLIAMS and COLIN WOOD* \\ From The London Hospital
}

(RECEIVED FOR PUBLICATION JANUARY 29, 1959)

It is unusual for hypoparathyroidism and steatorrhoea to occur together. In steatorrhoea the plasma phosphorus is often low and the serum calcium either low or normal (Salvesen and Böe, 1953). Rarely there is marked elevation of the plasma phosphorus, denoting failure of parathyroid function, and symptoms of severe hypocalcaemia dominate the clinical picture.

The cases illustrating this association were reviewed by Jackson (1957). Some of these showed additional abnormalities such as hepatitis and adrenal failure, but hypoparathyroidism and steatorrhoea were the only constant features and interest has largely centred on the aetiological relationship of the one to the other.

\section{Case History}

First Hospital Admission. A girl aged 6 years was admitted to the Manchester Royal Infirmary on October 27, 1953, with acute meningo-encephalitis. For three weeks she had complained of increasing frontal headache and on the day before admission had had repeated epileptic convulsions, at least 50 during the course of the day. At the beginning of her illness she had also complained of cough and was prescribed sulphadiazine, but the drug had to be discontinued because of urticaria.

In June, 1953, urticaria had followed the use of penicillin and chlortetracycline for pneumonia, and on other occasions she had been found to be sensitive to phenobarbitone. Previous illnesses included measles, mumps, German measles and chickenpox, all before the age of 5 years.

At birth she was a month premature, weighing $5 \mathrm{lb}$., but her early development had been normal. Her parents and both her sisters, aged 11 and 4 years, were healthy.

On examination she was drowsy, temperature $99 \cdot 2^{\circ} \mathrm{F}$. with, at first, slight neck stiffness. There were no other abnormal findings.

The following investigations were carried out:

27.10.53. Serum calcium $10 \mathrm{mg}$. \%. Inorganic phosphate $5 \mathrm{mg}$. \%. Lumbar puncture: C.S.F. leuco-

* Present address: University of Maryland Department of Pathology, 31 S. Greene Street, Baltimore 1, Md, U.S.A. cytes 107 per c.mm. (polymorphs 27 per c.mm., lymphocytes 71 per c.mm., mononuclears 9 per c.mm.); protein $35 \mathrm{mg}$. \%; sugar $53 \mathrm{mg}$. \%; chloride $720 \mathrm{mg}$. \%; Z.N. film, no tubercle bacilli seen. Culture sterile. Complement fixation tests for influenza $\mathbf{A}$ and $\mathbf{B}$, $\mathbf{Q}$ fever, psittacosis and lymphocytic choriomeningitis were negative. Tests for cold agglutinins and agglutination with streptococcus M.G. were also negative.

She improved rapidly, during her stay in hospital had no more convulsions, and was discharged home after three weeks.

Second Hospital Admission. Four months later on March 6, 1954, she was admitted to the Royal Liverpool Children's Hospital. For six weeks her stools had been frequent, bulky, loose and pale, and for four weeks she had complained of cramps with carpopedal spasms due to tetany. The serum calcium on February 2 was $5.9 \mathrm{mg} . \%$ and inorganic phosphate $5.8 \mathrm{mg}$. \%. Until admission she had been treated with parathormone and calcium intravenously, with some relief of symptoms.

On examination she was pale and thin; height $3 \mathrm{ft} .9 \mathrm{in}$., weight 2 st. $11 \mathrm{lb}$. Her tongue was clean and she was afebrile. There was moderate abdominal distension, liver and spleen being impalpable. Chvostek's sign was weakly positive.

Investigations showed: Haemoglobin $82 \%$. W.B.C. 10,000 per c.mm. Serum calcium $7 \cdot 2 \mathrm{mg}$. \%. Inorganic phosphorus $6.0 \mathrm{mg} . \%$. Radiographs of chest and bones were normal. Barium meal and follow-through examination showed slight segmentation of barium in the small intestine, with colon stasis and a redundant looped descending colon. The stools were large, pale, offensive and unformed. They contained no pathogenic organisms on culture. Trypsin was present to a dilution of $1 / 10$.

She was treated with a low residue gluten-free diet containing $25 \mathrm{~g}$. fat daily, and with vitamin D 2,000 units daily. Tetany improved, her weight increased $7 \mathrm{lb}$., but the stools were unaltered. She returned home on April 16.

Third Hospital Admission. The carpopedal spasms recurred, however, with attacks especially in the early mornings, and on June 3, 1954, she was re-admitted, having had parathyroid 20 U.S.P. units intramuscularly daily for 26 days and Collosol Calcium $2 \mathrm{ml}$. intramuscularly on alternate days. 
It was now noted that her skin was dry and her nails longitudinally ridged. Serum calcium on June 4 was $9.7 \mathrm{mg}$. \%, inorganic phosphorus $6.0 \mathrm{mg}$. \% and plasma proteins $7.5 \mathrm{~g} . \%$.

Treatment was at first withheld and on June 21 the serum calcium was $7.7 \mathrm{mg}$. $\%$, and the inorganic phosphate $6.0 \mathrm{mg}$. \%. A week later calciferol 50,000 units daily by mouth was commenced. She was discharged on July 13.

Fourth Hospital Admission. At home tetany persisted despite treatment with a gluten-free diet, calciferol and calcium and on January 12, 1955, she entered the Royal Liverpool Children's Hospital for the third time. For four weeks, following a cold, attacks of tetany had been severe and prolonged, being partially relieved by intramuscular calcium gluconate and injections of parathyroid 25 U.S.P. units two or three times daily. Her appetite had been poor for a week and she had become slightly jaundiced. An epidemic of infective hepatitis was prevalent at the time.

The serum calcium was now $11.6 \mathrm{mg}$. \%, inorganic phosphorus $6 \mathrm{mg}$. \%. Plasma proteins $7 \mathrm{~g}$. \%, serum bilirubin $3 \mathrm{mg}$. \% and alkaline phosphatase $23 \mathrm{King}-$ Armstrong units. Chromatography of the urine revealed a normal amino acid output.

She was treated with calciferol 20,000 units daily and a gluten-free diet. Jaundice at first deepened and then gradually cleared. Tetany, however, persisted and bilateral lens opacities appeared leading to impairment of vision. On March 14 the serum calcium was $7 \mathrm{mg}$. \%, inorganic phosphorus $4.3 \mathrm{mg}$. \% and plasma proteins $5.5 \mathrm{~g}$. \%. On March 29 she was transferred to The London Hospital. During the journey, owing to her increased auditory acuity, she found the noise of the trains intensely distressing.

On examination at The London Hospital (at the age of 7 years 10 months, and 14 months after the onset of steatorrhoea and tetany) she was an intelligent, poorly nourished child, with moderate pallor and no jaundice. Height $3 \mathrm{ft} .11 \frac{1}{2}$ in. Weight 3 st. $3 \mathrm{lb}$. Her skin and hair were normal and nails soft and ridged. Her hands and feet were of normal proportions. A few teeth were carious, with hypoplasia of the enamel of the lower central incisors and lower permanent molars. Chvostek's and Trousseau's signs were strongly positive, but the limb reflexes were sluggish. The abdomen was distended. The liver and spleen were impalpable and there was no ascites. Bilateral lens opacities were obvious to the naked eye and visual acuity was reduced, R. 6/36 and L. $6 / 60$.

Investigations showed the following results: 30.3.55. Serum calcium $4.8 \mathrm{mg}$. per $100 \mathrm{ml}$. Plasma phosphorus $8 \mathrm{mg}$. per $100 \mathrm{ml}$. Serum bilirubin $1.5 \mathrm{mg}$. per $100 \mathrm{ml}$. Alkaline phosphatase $26 \mathrm{King}$-Armstrong units. Thymol turbidity $4 \cdot 1$ units. Plasma proteins $8 \cdot 1 \mathrm{~g}$. per $100 \mathrm{ml}$. (albumin $4.4 \mathrm{~g}$., globulin $3.7 \mathrm{~g}$.).

3.4.55. Serum calcium $4 \cdot 7 \mathrm{mg}$. per $100 \mathrm{ml}$. Plasma phosphorus $10.5 \mathrm{mg}$. per $100 \mathrm{ml}$.

20.4.55. Serum bilirubin $14.5 \mathrm{mg}$. per $100 \mathrm{ml}$. Alkaline phosphatase 26.0 units. Thymol turbidity
12.0 units. Plasma proteins $6.7 \mathrm{~g}$. per $100 \mathrm{ml}$. (albumin 4.0 g., globulin $2 \cdot 7$ g.). Fat balance test (six days) $79 \%$ absorption on a diet containing $50 \mathrm{~g}$. fat per day. Blood urea $36 \mathrm{mg}$. per $100 \mathrm{ml}$.

Radiological Studies. The bones showed slight generalized osteoporosis when compared with a normal control. Transverse growth lines were present in the metaphyses but there was no evidence of active rickets. The metacarpals were of normal length and no abnormal calcification was seen in the skull or elsewhere.

After two mouthfuls of a non-flocculating barium suspension the head of the barium column reached the ascending colon in three hours. Nothing was seen to suggest gross disease of the small intestine.

She was treated at first with calciferol 2,000 units daily by mouth and a gluten-free diet. From April 25 calciferol was given by intramuscular injection 100,000 units on alternate days, the dose being increased to 200,000 units on May 4 and to 500,000 units on May 11 . Oral calcium lactate $8 \mathrm{~g}$. daily increasing to $24 \mathrm{~g}$. daily, pancreatin, folic acid and vitamins were also prescribed.

The serum calcium and inorganic phosphate levels returned towards normal, $8 \cdot 2 \mathrm{mg}$. and $4 \cdot 7 \mathrm{mg}$. per $100 \mathrm{ml}$. on June 1, 1955, and tetany disappeared. But in April jaundice returned with ascites, a flapping tremor and foetor hepaticus, and after repeated episodes of coma the patient died on June 8, 1955.

Summary of Autopsy (P.M. 229/55). A diagnosis was made of subacute hepatitis, idiopathic steatorrhoea and atrophy of parathyroid and adrenal glands. The parathyroids were not identified macroscopically. Lipid was absent and there was great focal atrophy in the cortex of both adrenals (together $5.5 \mathrm{~g}$.). The pituitary $(0.4$ g. $)$, thyroid $(5 \cdot 5$ g. $)$, pancreas $(36 \cdot 5$ g.) and ovaries (together $3 \cdot 2 \mathrm{~g}$.) were normal. There was no glandular tissue at the site of the thymus. Skin and sclerae were jaundiced. There was serous ascites $(800 \mathrm{ml}$.). The liver was grossly atrophied with several large areas of soft bilestained and coarsely lobular regeneration nodules bordered by firmer, pale reddish-grey atrophied parenchyma (326 g.) (Fig. 1). The biliary system, hepatic and portal veins were normal as was the alimentary tract except for slight oedema of the mucosa of the terminal ileum. There was advanced fatty degeneration of the kidneys (together $163 \mathrm{~g}$.); the remainder of the urinary tract was normal. The genital organs were infantile.

Serous effusion (114 ml.) was found in the right pleural cavity, and delicate fibrous adhesions throughout the right pleura. There was partial collapse and congestion of the lower lobes of the lungs. The larynx, trachea and bronchi were normal. There was enlargement of congested cervical and paratracheal lymph nodes (up to $2 \mathrm{~cm}$. in diameter), and obsolete tuberculosis of one mesenteric gland. The brain was normal and there were no skeletal deformities, nor visible change in texture of right femur, vertebral bodies and ribs on section. Mixed haemopoietic and adipose marrow was found in the upper fifth of the femur. The calvaria was heavy without bossing. There was slight translucent mottling 


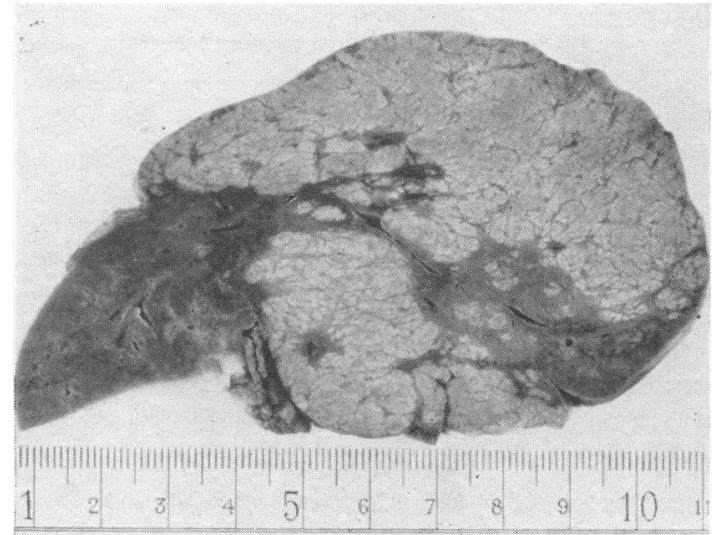

Fig. 1.-Gross atrophy of liver. Pale, coarsely lobular regeneration nodules. Coronal section.

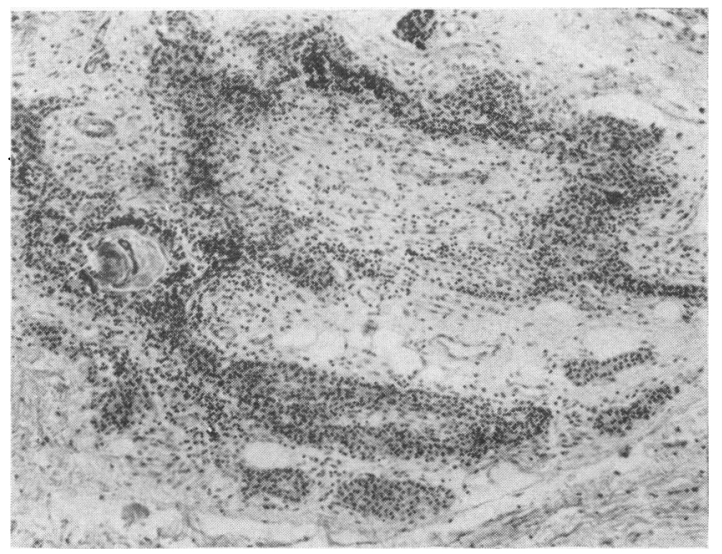

FIG. 2.-Parathyroid gland. Bands of two or more layers of epithelial cells, centrally replaced on one side of the field by lymphocytes, enclosing a Hassal's corpuscle. H. and E. $\times 75$.

of teeth. She was a moderately nourished girl (weight $23 \mathrm{~kg}$., length $122 \mathrm{~cm}$.). Mean for 8 years: $26 \cdot 35 \mathrm{~kg}$. (Stuart and Stevenson, 1950) and $128 \mathrm{~cm}$.

Microscopic Examination. Parathyroids. Two glands were found in sections of paraffin-embedded tissue posterior to the right lobe of thyroid; they measured $0.7 \times 0.5 \mathrm{~cm}$., and $0.5 \times 0.5 \mathrm{~cm}$. The greater part of these glands consisted of vascular fibrous tissue surrounding solid islands and bands of well defined, somewhat vacuolated epithelial cells resembling parathyroid chief cells (Figs. 2 and 3 ) and centrally replaced by lymphocytes. There were occasional small separate acini lined by cuboidal cells (Fig. 4). In addition both glands contained several concentrically laminated bodies of eosinophilic material ringed by nucleated flattened squamous cells, resembling Hassal's corpuscles (Fig. 2). These lay in the centre of mainly peripheral islands and bands of parathyroid-like tissue, and were separated by lymphocytes from the epithelial cells of parathyroid type.
There were also a few small cysts lined by low cuboidal epithelium, the larger of which contained cellular debris and structureless eosinophil material. Corresponding pieces of left cervical tissue included lobules of brown fat and small lymph glands but no parathyroid tissue.

THYmus. No thymic or parathyroid glandular tissue was identified in the anterior superior mediastinal adipose tissue. A few lymph nodes were seen.

ADRENAL. There was diffuse uneven infiltration of the cortex with small lymphocytes, associated with disruption of the normal cellular pattern, congestion, and marked but uneven atrophy (Fig. 5). The medullary cells were widely separated; their cytoplasm was stringy and vacuolated.

THYroID. In sections of the right and left lobes the vesicles were packed with well-stained colloid and lined by low cuboidal cells. There was no lymphocytic infiltration, and no included parathyroid tissue.

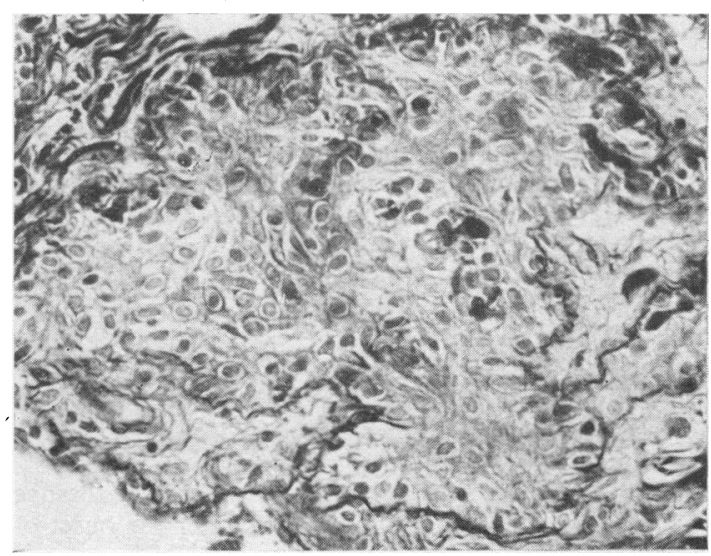

FIG. 3.-Parathyroid gland. Island of well defined epithelial cells, resembling chief cells. Masson's trichrome $\times 290$.

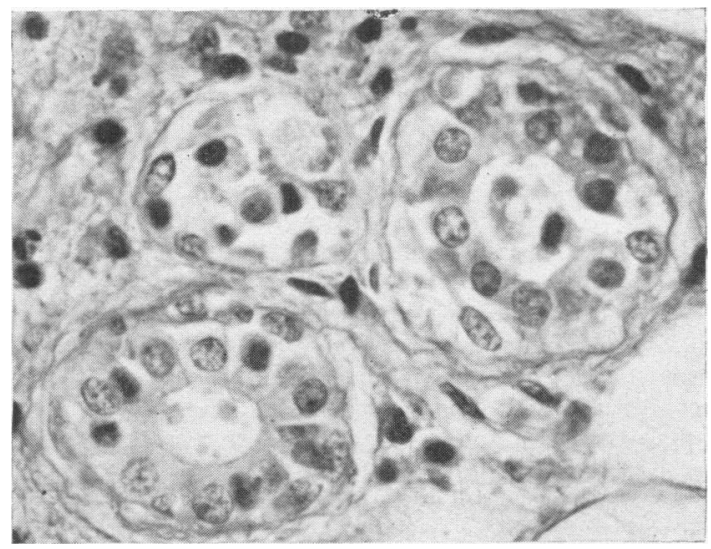

FIG. 4.-Parathyroid gland. Acini lined by cuboidal cells. Van Gieson $\times 650$. 


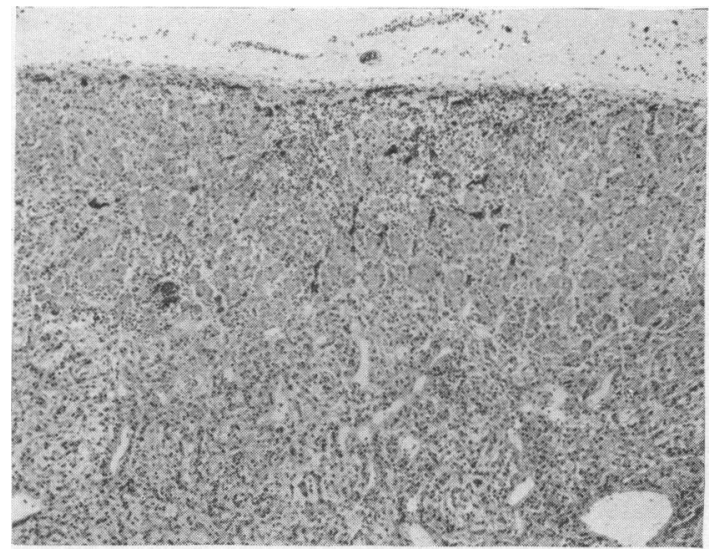

Fig. 5.-Adrenal cortical atrophy. The full thickness of cortex, and part of the medulla is showm. H. and E. $\times 48$.

Pancreas. Abundant islets were seen in the moderately autolysed pancreas. There was no evidence of inflammation, fibrosis, or cysts.

Pituitary. No abnormality seen. The basophil cells were numerically within normal limits.

OVARY. This contained several cystic primordial and atretic follicles.

LIVER. Coarse nodules of autolysed, regenerated liver cells, including areas of fatty change, were separated by granulation tissue. Here the lobules were collapsed, with a condensed reticulin framework, and showed marked lymphocytic infiltration, proliferation of surviving bile ducts, and periportal fibrosis (Fig. 6).

No abnormality was found in sections of small intestine, colon, mesenteric lymph node and submandibular salivary gland.

KIDNEY. There was conspicuous fatty degeneration of the tubular epithelium. The lipid was devoid of cholesterol esters.

Bones. Sections of the femoral head and greater trochanter, vertebra and costochondral junction wère compared with control sections from a child of the same age (sudden accidental death). The epiphyseal cartilage of conjugation in the femoral head was narrower than in the control, and the zones of provisional calcification here and in the other epiphyses were very defective. There was little evidence of either osteogenesis or absorption of bone judging by the paucity of osteoblasts and osteoclasts.

\section{Discussion}

The main features in the seven previously reported examples of this syndrome have been summarized by Jackson (1957). The sexes have been equally affected and the age of onset has ranged from early infancy (Lowe, Ellinger, Wright and Stauffer, 1950)

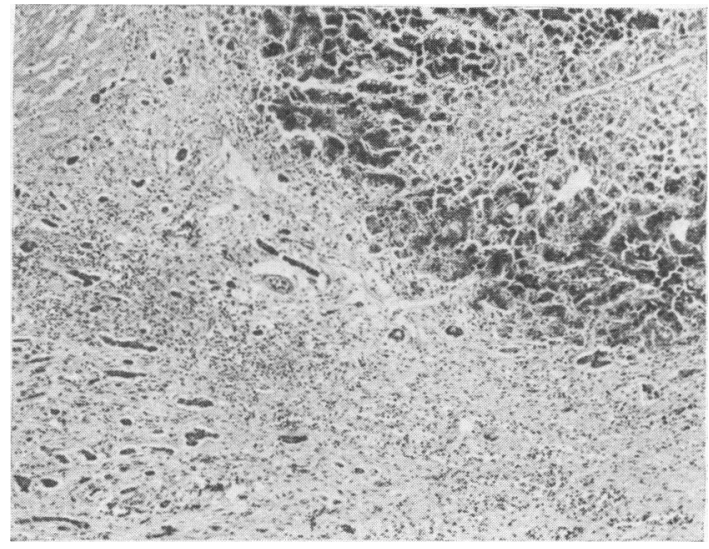

FIG. 6.-Hepatic regeneration nodule bordered by granulation tissue containing small bile ducts. H. and E. $\times 52$.

to 32 years. Salvesen (1957) attributes the hypocalcaemia in these cases to pre-existing hypoparathyroidism, the later development of steatorrhoea with faecal loss of calcium acting as an aggravating factor. But in none has hypoparathyroidism been evident clinically before the onset of steatorrhoea, and indeed in our patient the serum calcium was shown to be normal four months before the onset of this feature. On the other hand hypoparathyroidism complicating prolonged steatorrhoea might be due to secondary or 'exhaustion' parathyroid atrophy. In the patient described by CollinsWilliams (1950) diarrhoea preceded tetany by 19 months, in Leifer and Hollander's (1953) by six months and in Jackson, Hoffenberg, Linder and Irwin's (1956) by two months. In our patient, however, this explanation cannot apply, for steatorrhoea and tetany appeared almost simultaneously.

The autopsy findings in two cases have failed to throw light on the pathogenesis of the hypoparathyroidism. In the case described by Castleman (1954) no parathyroid tissue was recognized. Similarly in ours no normal parathyroid glands or thymus were found in the sections of all the retrothyroid and anterior superior mediastinal connective tissue. Two epithelial glands were, however, identified in these sections. They were thought to contain parathyroid tissue, and if this interpretation is correct the glands were either hypoplastic, or extensively destroyed by necrosis, with inflammatory lymphocytic infiltration. The squamous corpuscles which each contained were regarded as inclusions of ectopic thymic tissue. This finding, however, does not provide evidence of congenital hypoplasia, for the combination of parathyroid and thymic tissues in the normal was carefully docu- 
mented by Gilmour $(1937,1938)$ and is explained by their common embryogenesis.

In seeking the cause of steatorrhoea in these cases it would have been of interest to observe the effect of gluten withdrawal. But this was done only in ours, the patient's negative response tending to rule out the usual form of coeliac disease. Histopathological changes at autopsy in idiopathic steatorrhoea are few (Bockus, 1944) and it need only be said that in the present case there was no pancreatic disease, intestinal mucosal atrophy or intestinal lipodystrophy. The associated findings of hepatitis and adrenal disease in some of the others suggest that in these too the cause of the steatorrhoea was unusual. The hepatitis is unlikely to be nutritional due to malabsorption, because it rarely complicates other forms of steatorrhoea, and in the same way although in steatorrhoea the adrenals have sometimes been implicated in explaining some of its clinical manifestations, frank adrenal failure with corresponding histological changes do not occur. Furthermore, though parathyroidectomy in dogs has led to necrosis of liver cells (Larson and Elkourie, 1928) there can in this syndrome be no causal relationship between the hypoparathyroidism and hepatitis, because the one does not invariably follow the other.

It can reasonably be postulated that the agent causing the steatorrhoea is also directly injurious to the parathyroid glands and other organs. But whether it is a virus or the syndrome can be explained on the basis of hypersensitivity is conjectural. The case report by Leifer and Hollander (1953) can perhaps be quoted in favour of allergy. The patient had had asthma since the age of 2 years and there was a strong family history of childhood eczema. Our patient was sensitive to barbiturates, sulphonamides and certain antibiotics and the 'meningo-encephalitis' which preceded steatorrhoea in her case may also have been allergic. More significant perhaps were the autopsy findings of parenchymatous atrophy and lymphocytic infiltration in the parathyroid and adrenal glands. Similar changes are found in the thyroid in Hashimoto's disease and in the adrenals in idiopathic Addison's disease, both of which have been ascribed to autoimmunization (Roitt, Doniach, Campbell and Hudson, 1956; Anderson, Goudie, Gray and Timbury, 1957).

Indications of virus infection are equally scanty. Though our patient presented with atypical pneumonia and encephalitis, the only evidence of virus infection at autopsy was found in the liver. Here the appearances were those of post-necrotic cirrhosis following infective hepatitis, an infection which in the present case may even have been coincidental. Idiopathic hypoparathyroidism has been attributed to virus infection (Drake, Albright, Bauer and Castleman, 1939) and in one case (Leonard, 1946) the histological appearances of meningo-encephalitis were found in the hypothalamus at autopsy. In three cases (Cantarow, Stewart and Morgan, 1939; Leonard, 1946; Perlmutter, Ellison, Norsa and Kantrowitz, 1956) there were inflammatory changes in the liver, in the last two of these Addison's disease being a later development.

There is indeed closer affinity between so-called idiopathic hypoparathyroidism and the syndrome of steatorrhoea complicated by hypoparathyroidism, than between this syndrome and gluten-induced coeliac disease, and it can at least be concluded that in the syndrome steatorrhoea is aetiologically not the primary disorder.

\section{Summary}

A child aged 6 years 8 months developed steatorrhoea and hypoparathyroidism four months after an acute illness diagnosed as meningo-encephalitis.

She died of liver failure and autopsy revealed subacute hepatitis with atrophy of the parathyroid and adrenal glands. The alimentary tract was normal.

Previous examples of this syndrome are reviewed and its possible aetiology considered.

We are grateful to Dr. F. R. Ferguson, Professor N. B. Capon and Dr. Donald Hunter for permission to publish this case and to Dr. Hunter and Professor Dorothy Russell for their helpful advice and criticism.

\section{REFERENCES}

Anderson, J. R. Goudie, R. B., Gray, K. G. and Timbury, G. C. (1957). Lancet, 1, 1123.

Bockus, H. L. (1944). Gastroenterology. Saunders, Philadelphia and London.

Cantarow, A., Stewart, H. L. and Morgan, D. R. (1939). Endocrinology, 24, 556 .

Castleman, $B$. (1954). In the case records of the Massachusetts General Hospital, New Engl. J. Med., 251, 442.

Collins-Williams, C. (1950). Pediatrics, 5, 998.

Drake, T. G., Albright, F., Bauer, W. and Castleman, B. (1939) Ann. intern. Med., 12, 1751.

Gilmour, J. R. (1937). J. Path. Bact., 45, 507.

- (1938). Ibid., 46, 133.

Jackson, W. P. U. (1957). Lancet, 1, 1086

Hoffenberg, R., Linder, G. C. and Irwin, L. (1956). J. clin. Endocr., 16, 1043.

Larson, E. and Elkourie, L. A. (1928). Amer. J. Physiol., 85, 387.

Leonard, M. F. (1946). J. clin. Endocr., 6, 493.

Leifer, E. and Hollander, W. (1953). Ibid., 13, 1264.

Lowe, C. U., Ellinger, A. J., Wright, W. S. and Stauffer, H. M. (1950). J. Pediat., 36, 1.

Perlmutter, M., Ellison, R. R. Norsa, L. and Kantrowitz, A. R. (1956). Amer. J. Med., 21, 634.

Roitt, I. M., Doniach, D., Campbell, P. N. and Hudson, R. V (1956). Lancet, 2, 820.

Salvesen, H. A. (1957). Ibid., 1, 1246.

- and Böe, J. (1953). Acta med. scand., 146, 290.

Stuart, H. C. and Stevenson, S. S. (1950). In Mitchell-Nelson Textbook of Pediatrics, ed. W. E. Nelson, 5th ed. Saunders, Philadelphia. 